\title{
CMP 用フュームドシリカスラリー調整条件とスクラッチ欠陥発生との相関関係
}

Relationship between dispersion condition of fumed silica CMP slurry and scratch defect generation

\author{
○学 伊藤吉彦・九大院
}

Yoshihiko ITOU, Kyushu University

正 土肥俊郎 - 九大

Toshiro DOI, Kyushu University

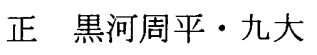

Syuhei KUROKAWA, Kyushu University

河野博之・九大

Hiroyuki KOUNO, Kyushu University

正 梅崎洋二・九大

Yoji UMEZAKI, Kyushu University
松川洋二・九大

Yoji MATSUKAWA, Kyushu University

Keywords: CMP(Chemical Mechanical Polishing), micro scratch, fumed silica, large particle

\section{1. 緒言}

LSI デバイス製造工程内のウエハ平坦化には, CMP (Chemical Mechanical Polishing) プロセスが適用されている。 しかし, CMP プロセスでは微細な加工欠陥の発生(マイクロ スクラッチやピットなど)が問題視されており, これら加工 欠陷低減の要求は, LSI 微細化に伴い厳しくなることは必至 である.

そこで本研究では, まずフュームドシリカスラリーによる 層間絶縁膜 $\left(\mathrm{SiO}_{2}\right.$ 膜)平坦化 $\mathrm{CMP}$ プロセスでの, マイクロス クラッチに着目して研究をす寸めている. スクラッチ発生要 因としてはスラリー中の粗大粒子が考えられており ${ }^{1)}$, その 大きさや個数はスラリー原料物性・調整条件でも変化する. 本研究ではフュームドシリカスラリーを試作し, スラリー原 料・調整条件が粗大粒子数と CMP 加工特性(スクラッチ久阫 発生密度)に及ぼす影響を, 定量的に評価することを目標と している.

前報告までは $\mathrm{SiO}_{2}$ 膜ウエハを試作スラリーで研磨し, レ 一ザ顕微鏡観察でスクラッチ欠陥発生密度を計測してきた ${ }^{2)}$. しかし，観測されるスクラッチが少なく(検鏡領域 $4 \times 8 \mathrm{~mm}$ で数個), スクラッチ欠陷発生に対するスラリ一調整条件の 影響を正しく評価できなかった.

そこで本報告では, $\mathrm{SiO}_{2}$ 膜より軟質でスクラッチを発生し やすいとされている $\mathrm{Cu}$ ウエハを研磨することで, フューム ドシリカスラリー調整条件（特に分散機の組み合わせ/水酸 化カリウム添加時期) が, 粗大粒子数やスクラッチ欠陥の発 生に及ぼす影響を調查したので以下報告する。

\section{2. 実験方法}

\section{2-1 スラリー試作と粗大粒子数の計測}

本実験ではフュームドシリカ粒子を超純水に分散させ, 水酸化カリウム $(\mathrm{KOH})$ を添加した 6 種のフュームドシリカス ラリーA,B,C,D,B',B”(砥粒濃度 $12.5 \mathrm{wt} \%$, pH10.6)を試作した。 その調整工程を図 1, 各工程で使用した機器・資材を表 1 に 示す. 予備分散には, インペラーミキサーやホモミキサーと 呼ばれる, 回転翼を利用した分散機を使用した. その後, 高 圧ホモジナイザー (キャビテーションを発生させて粒子の分 散を行う装置) を用いての高圧分散処理や, デプスフィルタ ーによるろ過を行った。
試作スラリー中の粗大粒子数 $($ 粒径 $\mathrm{D} \geqq 1.0 \mu \mathrm{m})$ は, 個数力ウ ント方式粒度分布計 AccuSizer780A(PSS 社製)で計測した。

\section{2-2 研磨実験とスクラッチ欠陥発生密度の計測}

研磨実験には卓上型ポリッシング装置 LM15 を用い, ウエ 八には 3 インチの $\mathrm{Cu}$ ウエハを用いた。 その他詳しい加工条 件については表 2 に示す.

ウエハにできたスクラッチ欠陥(図 2 参照)の発生密度は, 図 3 に示した領域をレーザ顕微鏡（微分干渉観察, 倍率 100 倍）で検鏡観察することにより計測した．なお本顕微鏡では 長さ $\mathrm{L} \geqq 0.5 \mu \mathrm{m}$, 幅 $\mathrm{W} \geqq 0.5 \mu \mathrm{m}$ のスクラッチを観察できる.

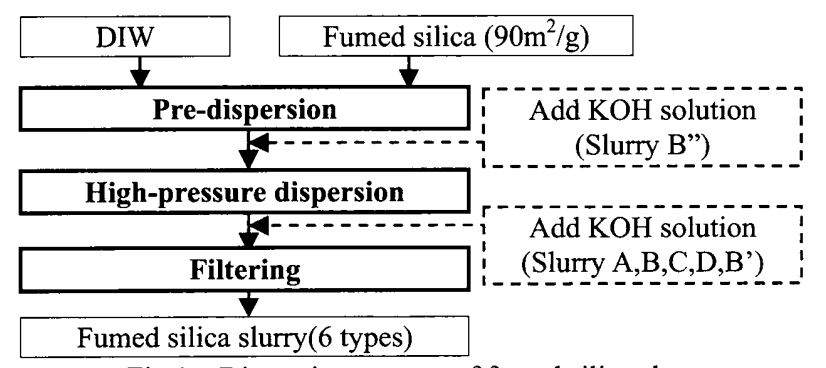

Fig.1 Dispersion process of fumed silica slurry

Table 1 Dispersion condition

\begin{tabular}{|c|c|c|c|c|}
\hline Sitinn & \multicolumn{2}{|c|}{ Hirdingersion } & Ifion & 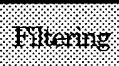 \\
\hline$\overline{\mathrm{A}}$ & \multirow{6}{*}{$\begin{array}{l}\text { Impeller } \\
\text { mixer } \\
\left(400 \text { min }^{-1}\right)\end{array}$} & \multirow{3}{*}{$\begin{array}{l}\text { Homomixer } \\
\left(10000 \mathrm{~min}^{-1)}\right.\end{array}$} & High-pressure & $1 \mu \mathrm{m}$ pore \\
\hline $\mathrm{B}$ & & & homogenizer(50MPa) & \multirow{5}{*}{ No } \\
\hline $\mathrm{C}$ & & & $\mathrm{No}$ & \\
\hline $\bar{D}$ & & \multirow{3}{*}{ No } & & \\
\hline $\mathrm{B}^{\prime}$ & & & High-pressure & \\
\hline $\mathrm{B}^{\prime \prime}$ & & & homogenizer(50MPa) & \\
\hline
\end{tabular}

Table 2 Polishing condition

\begin{tabular}{|c||c|}
\hline Polishing pad & IC1000/SUBA400(XY-groove) \\
\hline Wafer & $\mathrm{Cu} \mathrm{wafer}(\phi 3$ inches $)$ \\
\hline Polishing pressure & $10.8,16.2 \mathrm{kPa}$ \\
\hline Platen and wafer rotation speed & $60 \mathrm{~min}^{-1}$ \\
\hline Slurry & $\begin{array}{c}\text { Fumed silica slurry }(6 \text { types }) \\
(12.5 \mathrm{wt} \%, \mathrm{pH} 10.6)\end{array}$ \\
\hline Slurry flow rate & $50 \mathrm{~mL} / \mathrm{min}$ \\
\hline Polishing duration time & $2 \mathrm{~min}$ \\
\hline
\end{tabular}




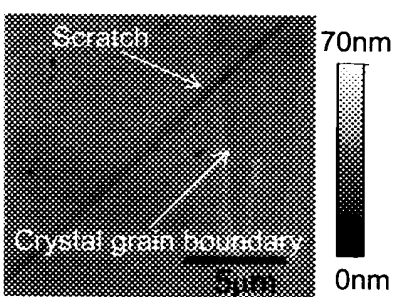

Fig.2 AFM image of scratch

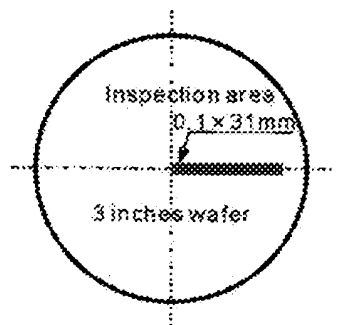

Fig.3 Inspection area

\section{3. 実験結果および考察}

3-1 $\mathrm{SiO}_{2}$ 膜と $\mathrm{Cu}$ ウエハでのスクラッチ欠陷密度の違い

試作スラリーB を前報告 ${ }^{2)}$ での $\mathrm{SiO}_{2}$ 膜の場合と比較した. 図 4 に実験結果を 示す. $\mathrm{Cu}$ ウエ八では, $\mathrm{SiO}_{2}$ 膜ウエハ加工時よりもスクラッ チ欠陷密度が顕著に高いことが分かる.これは $\mathrm{Cu}$ が $\mathrm{SiO}_{2}$ 膜 より軟質であるため, スクラッチを引き起こす粒子の影響を 受けやすくなったためと考えられる. またスクラッチ久陷を 適当量観察できたため， $\mathrm{Cu}$ ウエ八を用いた実験手法の可能 性が確かめられた。

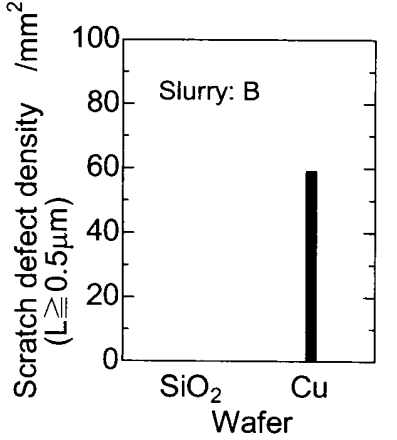

Fig.4 Scratch defect density on $\mathrm{SiO}_{2}$ and $\mathrm{Cu}$ wafer

\section{3-2 分散/ろ過操作の影響}

粗大粒子数やスクラッチ欠陷数に対する，スラリー分散/ ろ過の影響を調查した．スラリーA,B,B'C,D の粗大粒子数を 図 5(a)に，スクラッチ欠陷密度を図 5(b)に示寸。スラリー A,B,C,D の比較からホモミキサー/高圧ホモジナイザー/ろ過 処理で，予想どおり粗大粒子数は減少した。しかし，スクラ ッチ欠陥数はホモミキサー処理で逆に増加し, 高圧ホモジナ イザー処理では増減していない.このことはホモミキサー処 理工程で何らかのスクラッチの原因が増加したためと考え られる.

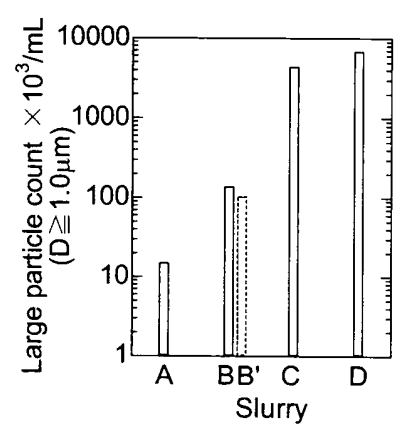

(a)Large particle count

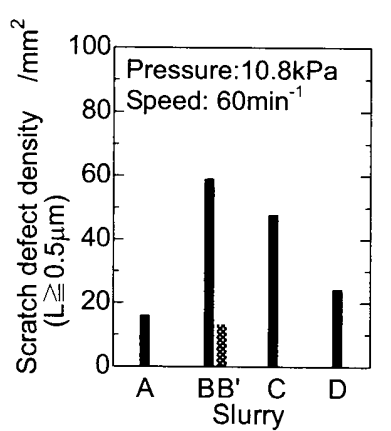

(b)Scratch defect density

Fig.5 Effect of dispersion machine and filter
そこでスラリーB の調整工程からホモミキサー処理を省 略して作成したスラリーB'を評価した，その結果，粗大粒子 数はスラリーB と同等だが，スクラッチ欠陷数は大きく減少 することが確認された．スクラッチの原因として，(1)ホモミ キサーの金属摩耗粉や，(2)ホモミキサーからの高せん断力に よる凝集粒子の発生が考えられ，今後これらへの対策が必要 である。

\section{3-3 $\mathrm{KOH}$ 添加時期の影響}

高せん断力による凝集粒子は高圧ホモジナイザーでも同 様に発生することが考えられる，そこでシリカのゼータ電位 を低下させ凝集の抑制効果がある $\mathrm{KOH}$ を，高圧ホモジナイ ザー処理の前に添加し(スラリーB”)，スクラッチ欠陷数を低 減できないか調查した．スラリーB',B”での粗大粒子数を図 6(a)にスクラッチ欠陥密度を図 6(b)に示す，粗大粒子数はほ ぼ同等であり，スクラッチ欠陥数は高圧分散前に $\mathrm{KOH}$ を添 加したスラリーB”の方が若干減少した。

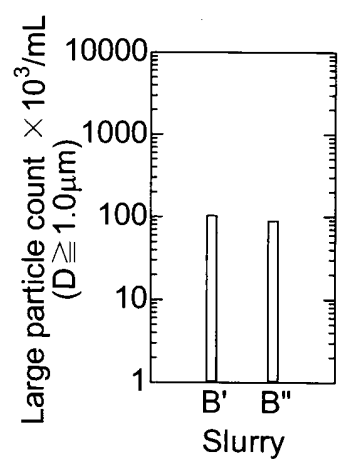

(a) Large particle count

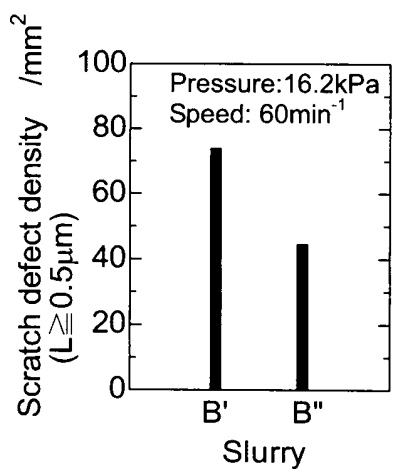

(b) Scratch defect density Fig.6 Effect of $\mathrm{KOH}$ adding timing

\section{4. 結言}

粗大粒子数やスクラッチ欠陥数に対する, スラリ一調整条 件の影響を調査し以下のことがわかった。

(1)粗大粒子数はホモミキサー/高圧ホモジナイザー/万過処理 で减少する. しかしスクラッチ欠陷数はホモミキサー処理 で増加してしまう.コンタミの発生などが考えられるため, 装置改良が必要である。

(2)水酸化カリウムの添加を高圧分散前に行うことでスクラ ッチ欠宿数を減少させることができた。

以上の結果を踏まえ，今後はホモミキサーの改良を行い， スラリー調整条件(高圧ホモジナイザ一圧カ/パス回数など) が粗大粒子数とスクラッチ欠陷数に及ぼす影響を調查する 予定である。

\section{参考文献}

1)プラナリゼーション CMP とその応用技術専門委員会,CMP 技術大系(2006),420-421

2)伊藤ら,精密工学会秋季大会学術講演会講演論文集(2009), 303-304 